\title{
Magical Music in Old Norse Literature
}

No society ever existed without performing music, and most cultures display many variants of music. Music also played and still plays an important part in different religious rites. From the days of yore, music has been intimately connected with the cult, whether it is performed as epic or lyric expressions.

The Old Norse society was no exception to this statement and early finds from as far back as the Bronze Age reveal that different instrument were used in daily life. The most conspicuous specimens from this time are the bronze lures, which probably are depicted on the rock-carvings. They were made in two different ways - a simpler model made in the shape of a big horn and a more elaborate one made as a big $\mathrm{S}$, which seems to appear in pairs: one curved to the left and the other to the right. Their size varied from $50 \mathrm{~cm}$ to more than $200 \mathrm{~cm}$. (Jacobsson 1975: 7). Modern musicians have manageded to produce five notes on the bigger ones, but it is uncertain whether the lures were used to play melodies. The practice of blowing one note for where two or more horn players replaced each other in a religious ritual has been suggested as a possible use of these huge bronze lures. (Lund 1994: 26-27). The great bronze shields from the same period seem to belong to the ritual ceremonies, of which we know hardly nothing. According to one hypothesis, these were used as drums, but since ceremonial swords and axes also appear among these finds, it is also conjectured that the weapons could have been used in a ritual war dance. There is also evidence of flutes made of bones and various kinds of rhythm instruments, such as drums, rattles and whiners. (Lund 1994: 24-25)

In the Viking Ages the literary sources tell us that music was performed as entertainment, especially at the royal court or in the hall of a famous chieftain. The music was performed by itinerant bards, some of them travelling far away, as Widsid, who was said to have visited India. Their instruments were the harp, which according to the Roman descriptions of the Germanic tribes, but there are also finds of lyres with six strings. In Ibn Fadlān's famous description of a Viking burial, the dead chieftain of the 
Rūs was equipped with a lyre among the other things in his grave (Wikander 1978: 67). A stringed instrument was also found in the ship burial of Sutton Hoo, wrapped in an animal skin bag, reconstructed as a round lyre. As a final suggestion about the origin of the harp we quote Roslyn Rensch:

...any people who owned the hunting bow had possession, in embryo, of the frame harp; anyone who inserted a twig between the converging string arm and sound chest of the harp-developed-from the bow (whether he originally achieved that development himself or borrowed it from an Eastern civilisation) had the prototype of the frame harp of western Europe. (Rensch 1969: 31)

The harp is an entertaining instrument in Beowulf but it also maddens the monster Grendel;

Pær wæs heapen sweg

swutol sang scopes

There was the sound of the harp, the clear song of the minstrel (Beowulf 1978: 89-90)

The origin of the harp has been discussed; some scholars maintain that it derives from the Celtic areas, especially Great Britain; others claim a Germanic provenance. (Rensch 1969: 28-29)

The harp is mentioned in Old Norse literature in Völuspá, the poem of the creation of the world and of its destruction. When the mythical ages decline and a different omen forebodes the descent of the gods' power, ragnarök, one of these is mentioned in stanza 41 :

Sat par á haufi

ok sló hörpo

gýgiar hirðir

glaðr Eggber
He sat on the mound and played on the harp, the shepherd of the giantess, the merry Eggper (Vsp. 41)

The giantess is mentioned in stanza 40 as "the old woman in the Ironwood" who bred Fenrir's off-spring. Fenrir the wolf was one of the terrible monsters, sired by Loki, who threatened the gods and the cosmic order. His offspring included the wolves appearing at the beginning of ragnarök, which Egger seemed to have herded. He was obviously full of expectation faced with the future battle between the gods and the giants and perhaps he even incited the wolves with his music. This would be a better explanation of the stanza - in my opinion - than the allusion to King David in Old Testament, who also was a great musician on the harp, but in fact had nothing to do with the context. 
One widespread motif that survived into the Christian iconography was Gunnar in the snake pit, an episode in the Saga of the Volsungs:

King Gunnar was then placed in a snake pit with many serpents, and his hands were bound fast. Gudrun sent him a harp and he showed his skill by artfully plucking the strings with his toes. He played so exceedingly well that few thought they had heard such strumming even with the hands. And he continued playing skilfully until all the serpents had fallen asleep, except for one large and hideous adder which crawled up to him and burrowed with its head until it struck his heart. And there, with much valour, Gunnar lost his life. (Saga of the Volsungs 1993: 102)

Gunnar enchanting the snakes echoes the old motif in which a musician managed to bewitch nature and goes back to Orfeus, who played the lyre surrounded by listening animals and who subdued even Hades to open his gates to the nether world. Magical music is also reflected in several Celtic myths, where men are said to have died during the performance caused by the ability of the minstrel. This dramatic effect on people's minds is also evident in the late fornaldarsaga about Bosi. The hero of this saga, Bosi, tries to free a princess captured by the mythical King Guormundr of Glæsisvellir. Guômundr resides in a kingdom in Bjarmaland and personifies an ambiguous person, sometimes benevolent, sometimes ill-intentious, characteristics reminiscent of Óðinn himself. In this episode he appears to be conspicuously weak, when Bosi enters the wedding between the captured princess and a man called Siggeir disguised as the minstrel Siguror. The ceremony begins with a toast to Pórr. After that Bosi begins to play and sing his first song, with the effect that every movable thing in the hall is aroused and some people begin to dance. This playing went on for a while. Then a toast was proposed to all the Esir, and Bosi played so that the hall echoed with the sounds; first he played only pieces of music, but then he performed Gygjarslag, Drambus and Hjarrandi. As the guests were drinking the toast to Oðinn, he played Faldefyki on his biggest harp, which caused the veils on the women's heads to falter. By now, everyone was dancing. The last toast at the wedding was the one to Freyja, and when Bosi played Ramnaslag, even the king and Guomundr and the guard were dancing, which gave him the opportunity to hide the princess in the big harp and to carry her away. (B6sa saga ok Herrauðs 1954-76: 310-313)

This reminds us of another mythical tale, about Áslög, the daughter of Siguror Fafnisbani and Brynhildr, who was, according to another fornaldarsaga about Ragnar Loðbrok, hidden in a harp and brought to Norway. (Ragnars saga loðbrókar 1954-76: 221-222). One might object that these stories cannot exactly be regarded as documents about the perform- 
ance of music. Yet Bosa saga mentions a number of songs that might have been popular and had their place at the great banquets during the Viking Age.

The power of the harp is described by Saxo on several occasions, but most pivotal is the description about Hotherus in his third book:

His richly endowed mind made him outstrip his unripe years. No one was a more expert harpist or lute-player, as well as which he was dextrous in the whole art of the psaltery, lyre and fiddle. By performing in different modes he could excite in men's breasts whatever emotions he wished, joy, sorrow, pity and hatred, and by delighting or dismaying their ears could capture their minds. (Saxo 1979-80: 69)

Hotherus' capacity to excite people's minds with his music was useful in his perpetual battle with Balderus. This god was nourished by a special drink mixed by three supernatural sisters dwelling in the forest. Hotherus now endeavours to get that drink for himself:

Being handed a lyre, he tuned the strings, set his plectrum to it and played with the most fluent expressiveness to a ravishing cascade of song. They also had three snakes there, whose poison normally provided a potent preparation to be mixed with Balder's food; even now the venom was dripping in large quantities from their open jaws on to his meal. One of the nymphs, unbending towards Høther, would have offered him a share of this banquet, had not the eldest interposed and protested that Balder would suffer deprivation if they enriched his adversary with additional strength. (Saxo 1979-80/1: 75)

The passage ends with a lacuna, but it seems somehow that Hotherus had convinced the three maidens to supply him with the magical drink.

The power of the harp is well-known in later folk-songs and ballads, where it forms a recurrent theme. Music had the power to help people escape from evil forces, as in the ballad about the wedding where Näcken, the evil spirit of the water, abducts the bride as she is riding over a bridge; the bridegroom takes his harp and begins to play. The music has magic consequences - the bark is peeled off the trees; the grass disappears from the meadow and finally Näcken himself arises from the deep, weeping and returning the bride. (SMB 1983: 22:268). This is not the case in several other ballads, where Näcken, disguised as a nobleman, allures a young woman or a man down into the deep. (SMB 1983: 20: 229)

Näcken was an evil spirit of the rivers and waterfalls, probably derived from the verb, nigu, "wash, bathe". A comment made by a medieval theologian, Gottfried of Ghemens tells that he was a fallen angel, who played the dulcimer, an instrument which he brought with him when he was expelled from heaven. His origin is, however, traced back to pre-Christian 
times, where he appears as a Proteus-shaped demon, sometimes as a horse (Landnamabók 1925: 57), sometimes as a man, related to sea-spirits as Egir and Rán, a demonic creature who demands a tribute of human life. In order to allure people down to him, he plays the harp, later the fiddle. (Strömbäck 1981: 432-438)

The harp (or the lyre) is one of the most significant instruments in Old Norse literature. Used as entertainment at a royal banquet, it seemed peaceful enough, but it could - in the right or wrong hands - suddenly change into a powerful tool with which it was possible to gain ascendancy over individuals. Its magico-religious capacity is evident from an early, preChristian period until the Middle Ages, when certain types of music became the tools of the fallen angels which seduced mankind and ruined their hopes of salvation.

\section{The War Song}

Compared with the evidence of the wide-spread belief in the mystical power of the harp, the war song may seem more concrete and distinct. Its purpose is clear - to incite men's fighting spirits before a battle. For this purpose Chanson de Roland was sung by the Normans before the battle of Hastings. (Much 1959: 49). In Fostbroedrasaga's account of the battle of Stiklastad we are told that Pormoòr Kolbrúnarskald recited Bjarkamál with the beginning "Dagr's er uppkominn" in order to hearten the king's army. (Fóstbrœora saga 1943: 262-263). Heimskringla merely reports that the army of the yeomen cried and beat their shields. The war cry was able to cause a battle-panic - according to many sagas - which made people run away into the forest and eventually turn into an animal's shape. (Gundersen 1981: 282-283)

Strangely enough, other examples of battle hymns in the Old Norse literature are few, something that would be expected from such a belligerent people as the Vikings. There is, however, one possible example interpolated with the framework in Brennu-Njáls saga, where a man called Dörruorr sees twelve armed men riding into the women's house. (Brennu-Njáls saga 1954: 454-458) Looking in through the window, he beholds a terrible scene: Women are weaving with weights of human heads, their weft and warp consisting of human intestines; their reeds are swords and their weavingcomb arrows. They are singing a song about the battle while weaving the warrior banner for the army, prophesying victory for the young King and defeat for the Irish. 
We weave, we weave the web of the spear as on goes the standard to the brave we shall not let him lose his life The Valkyries have power to choose the slain (6).

All sinister now to see a cloud of blood moves over the sky the air is red with the blood of men as the battle-women chant their song (9).

(Translation from Anglo-Saxon and Norse Poems, by N. Kershaw, Cambridge, 1922)

As the outcome of the battle of Clontarf was in fact the opposite, we may draw the conclusion that Darraðarljó belongs to another context than Brennu-Njáls saga but has for some reason been inserted into it by its author. Already the uncommon name Dörruðr is probably a construction made from the title of the song, Darradarljód. Furthermore, to look through a window sometimes entailed taking part in a supernatural vision, like the slave-girl in Ibn Fadlān's story or the housewife in Völsa páttr.

There are, in fact, certain stanzas in the poem alluding to the battle at Clontarf, such as the death of Siguror jarl; others, like the recurrent homage of the young King, are more hard to interpret, as King Brian perished at the beginning of the battle. The last stanza ends with the inciting appeal: "let us ride away quickly on unsaddled horse and swords in hand!". This suggests a battle hymn, with the function of instilling courage in the warriors before combat and a signal to attack.

The women in the hymn are easyly recognised as Valkyries, the female deities whose names mean "those who are going to select the slain". In this situation they are singing a returning stanza Vindum, vindum vefr darraðr, "We weave, we weave the web of the spear". The web of the spear has sometimes been interpreted as "web of the Spear-God", Oðinn. Anne Holtsmark has, however, suggested that vefr darraðr should mean a banner or a standard, alluding to what was called a merki in the descriptions of the battles. In this episode of the saga this merki had a particular role. It belonged to Sigurr jarl, the leader of the heathen army, thus representing the bad guy, and it portrayed a raven, a bird carrying strong symbolic value of battle and death on the battle-field. The standard was woven by the earl's mother, skilled in magic, and it had the characteristic that it gave victory to the one for whom it was carried - i.e. the commander - but brought death to anyone who carried it, the merkismaðr or the standard- bearer". During the battle of Clontarf two standard-bearers fell and the jarl therefore asked the third to take up the banner, who answered: "You might 
carry your devil yourself!." The jarl then took the banner himself but fell immediately. (Holtsmark 1956:192-193)

Regarding this interpretation of vefr darraðr, it is, in my opinion, quite reasonable to assume that Darraðarljoð was originally a war song, recited before a battle in order to provoke a fighting spirit among the combatants. Tacitus already mentions a kind of battle song, although wordless, performed by the Germanic tribes before a battle:

They have also those cries by the utterance of which - "barritus" is the name they use - they inspire courage; and they divine the fortunes of the coming battle from the circumstances of the cry. Intimidation or timidity depends on the concerts of the warriors, it seems to them to mean not so much unison of voices, as union of hearts; the object they specially seek is a certain volume of hoarseness, a crashing roar, their shield being brought up to their lips, that the voice may swell to a fuller and deeper note by means of the echo. (Tacitus 1954: Ch. 3)

Tacitus' account has a counterpart in Hávamál 156, where the battle god par excellence, Óðinn, says:

bat kan ek it ellipta

ef ek skal til orrosto

leiða langveini

undir randir ek gel

en peir með rík, fara

heilir hildar til

heilir hildar frá

komo peir heilir hvaðan
I know that in the eleventh place if I go with good friends to the battle I sing towards my shield and. enchant the war to appear enchant the war to disappear that they will return safely (Hvm 157)

Singing toward the shield once again reminds us of ritual shields of the Bronze Age, although the space in time prevents us from speculations of a direct continuity.

This kind of song indicates the outcome of the battle rather than the agitation of an army against the enemy. This leads us to the special term vigspá, a kind of sorcery which turned success in the field to personal favour. It is mentioned in Völuspá in relation to "the first battle in the world" between the Asir and the Vanir. It is the Vanir that use this technique, and their women were also skilled in the kind of sorcery that was called sejor. In an earlier strophe one or two of these female Vanir had infiltrated even Ódinn's hall and used their sorcery against the Æsir. This was possibly an appearance of Freyja, who according to Heimskringla was the one that taught Óðinn the art of sejðr. 


\section{Galdr - the Magic Song}

A characteristic feature of sejor was the singing of a special song, galdr. (Strömbäck 1935: 119) Galdr derives from a similar stem to gala "to crow", which means that the song was performed loudly in a shrill voice. The music historians sometimes relate the special art of singing that was performed by saeter girls, cattle-tenders in the forest pastures calling home the cows in the far distance, the kulning. A kulning was performed at a special vocal pitch, shrill and piercing, and could be heard over a vast area. This is, however, a pure guess, since we know nothing about the performance of a galdr. (Lund 1994: 38)

The master of galdr was Óðinn himself, also called galds faðir. The stanza of Hávamál mentioned tells that unðir randir ek gel "I sing (a galdr) towards the shield", and later on in the same poem he relates the following:

Pat kann ek et fiórða / ef mér fyrðar

bera / bönd at

bóglimom/suá ek

gel / at ek ganga

má/sprettr mér af

fótom fiöturrlen af

höndom hapt
I know that for the fourth, if people bind my limbs with fetters, then I chant that I can walk, loosening the fetter from my feet and the chain from my hands.(Hvm.149)

This war fetter appears to be a special form of magic paralysis that belongs to the realm of sejdr and it is found in The First Merseburger Galder, an incantation belonging to the ninth century:

Eiris sâzun idisi sâzun

hera duoder/suma

hapt heptidun suma

heri lezidun/suma

clûbôdum umbi

cuoniouuidi/insprinc

haptbandun, invar

vīgandum!
Once mighty women sat here and over there, some tied fetters, some stopped the armies, some loosened the fetters. Dash out of the fetters! Run from the enemies!

This charm could have been recited before battle, with a view to invoking these powers to decide the outcome of the struggle, another example of vígspá. The mighty women are probably the Valkyries, and typically enough, one of these deities carries the name Herfjötur (Grm. 36), "the war fetter", 
alluding to the magic paralysis which could, by certain charms, fetter a warrior, making him an easy target for his enemies.

The Second Merseburger Galder displays another effect of the galdr:

Phol ende Uuodan vuorun zi holza

du uart demo balderes volon sin vuoz birenkiet

thu biguolen Sinhtgunt Sunna era suister

thu biguolen Friia Volla era suister

thu biguolen Uuodan so he vuola conda

sose benrenki sose bluotrenki sose lididrenki

ben zi bena bluot zi bluoda lid zi geliden sose gelimida sin.
Phol and Wodan went to the forest

Then Baldr's horse sprained its foot, then Sinhtgunt, the sister of Sunna charmed it, then Frija, the sister of Volla charmed it. then Wodan charmed it, as he was well able to do. Be it sprain of the bone, be it sprain of blood, be it sprain of the limb: bone to bone, blood to blood limb to limb, thus be they fitted together.

This spell does, as F. Ohrt has shown, display close similarities with a song in Atarvaveda which also instructs how to handle a sprain. (Ohrt 1925: passim) Galdr was used in medicine in many ways, as one example in Oddrúnarkviðda, where Óddrún delivers Borgný:

ríkt gól Oddrún

rammt gól Oddrún

bitra galdra

at Borgnýja
Oddrún chanted mighty Oddrún chanted strongly keen galdrar at Borgný('s bed).

(Odd. 7 )

Galdr could be used as a curse and the best example is found in Skirnismál: the fertility god Freyr has fallen in love, at first sight, with Geror, daughter of the giant Gymir. He sends his servant Skírnir ("the shining one"), who is none less than a hypostasis of the god himself, to propose to the girl. Skírnir finds Gerðr exceedingly hostile to his errand and begins by offering her golden apples and the ring Draupnir, which produces eight golden rings every ninth night. Geror refuses icily. He threatens her with his sword, but she takes no notice. Skírnir now utters a curse, charged with maledictions, intensified when the poem changes its metre from ljóaháttr into galdralag, the metre of spells:

Listen giants, listen frost-giants, sons of Suttungr, all kin of Esir how I deny, how I forbid the girl from man's joy, the girl from man's use! 
Hrímgrimnir is the giant, who shall have you down at the gates of Hel; where 'Vilmegir' will serve you goats' piss live on the wooden roots. You will never get a nobler drink, of my will, of your will.

I carve a purs-rune for you and three staves: defilement, lechery and concupiscence! I will carve them off like I (once) carved them, if that is needed (Skm. 34-36).

This curse breaks Gerðr's resistance and she makes Skírnir a promise: Barri is the name of a grove where we both may meet in peace; in nine nights Gerðr will joyfully love Njörðr's son (Skm.41).

A particular role of this kind of song is described in Eiriks saga raua, called the locus classicus of the sejðr by Dag Strömbäck. (Strömbäck 1935: 50) The appearance of a völva "a sibyl" takes place in a farmstead on Greenland, where she prepares the rites for the divination. She asks the women of the house if anyone of them could sing a song called Varblokkur, which she needed to entice the supernatural beings who brought her the prophecy. She then entered sejohjall, the special seat where she received knowledge from the supernatural world, and one young women sang the song. After that the völva was able to answer questions from the present about the coming year. (Strömbäck 1935: 52-54)

All these examples emphasise the character of music in Old Norse literature as connected with the magic aspect of religion, and particularly with divination. This does not mean that all music in the Viking Age was performed with a magic purpose, but what has survived in the sources is the conspicuous role of music as something that affected the human mind to the extent that it was experienced as a magic feeling, even able to reveal the future.

\section{References Cited}

Beowulf

1978 Beowulf. Ed. by Michael Swanton. Manchester: Manchester University Press.

Bósa saga ok Herrauds

1954-76 Bósa saga ok Herraus. In: Guðni Jonsson (ed.), Fornaldar sögur Norourlanda; vol. 3; pp. 281-322 S. 1.: s. n. (Íslendingasagnaútgáfan)

Brennu-Njáls saga

1954 Brennu-Njáls saga. Ed.Einar Ól. Sveinsson. Reykjavík: Hið íslenzka fornritafélag. (Íslenzk fornrit, 12) 
Fóstbroðra saga

1943 Fóstbrœőra saga In: Björn K. Pórólfsson and Guŏni Jónsson.(eds.), Vestfirððinga sögur; 119-276. Reykjavík: Hið íslenzka fornritafélag. (Íslenzk fornrit, 6)

\section{Gundersen, Dag}

1981 Krigsrop. In: Kulturhistoriskt lexikon för nordisk medeltid; vol. 9; pp. 282-283. København: Rosenkilde og Bagger. [ $2^{\text {nd }}$ ed.]

Holtsmark, Anne

1956 Studier i norrøn diktning. Oslo: Gyldendals norsk forlag.

Jacobson, Stig

1975 Musiken i Sverige. Skivlyssnarens handbok i svensk musik från äldsta tid till 1970-talet med utförlig skivförteckning. Västerås: ICAförlaget.

Landnamabók

1925 Landnamabók. Ed. Finnur Jónsson. København.

Ling, Jan

1983 Europas musikhistoria; vol. 1. Uppsala: Esselte studium.

Lund, Cajsa

1994 Forntiden. In: Leif Jonsson (ed.), Musiken i Sverige; vol 1: Leif Jonsson [et al]., Från forntid till stormaktstidens slut. Stockholm: T. Fischer \& Co. (Kungl. Musikaliska akademiens skriftserie, 74, 1)

Much, Rudolf

1959 Die Germania des Tacitus. Darmstadt: Wissenschaftliches Buchgesellschaft. [ $2^{\text {nd }}$ ed.]

Ohrt, Ferdnand

1927 Da signed Krist. Köpenhamn.

Ragnars saga loðbrókar

1954-76 Ragnars saga loðbrókar. In: Guð̃ni Jonsson (ed.), Fornaldar sögur Norðurlanda; vol. 1; pp. 219-285 S. 1.: s. n. (Íslendingasagnaútgáfan)

Rensch, Roslyn

1969 The Harp: Its History, Technique and Repertoire. London: Duckworth.

SMB Sveriges medeltida ballader

1983 Sveriges medeltida ballader; vol. 1. Ed. Bengt R. Jonsson. Stockholm: Almqvist och Wiksell International.

Saga of the Volsungs

1993 The Saga of the Volsungs. The Norse Epic of Sigurd the Dragon slayer. Intr. and transl. by Jesse L. Byock. Berkeley: University of California Press.

Saxo, Grammaticus

1979-80 The History of the Danes. 2 vols. Ed. Hilda Ellis Davidson. Cambridge: D. S. Brewer.

Strömbäck, Dag

1935 Sejd. Textstudier i nordisk religionshistoria. Stockholm: Geber.

1981 Näcken. In: Kulturhistoriskt lexikon för nordisk medeltid; vol. 12; pp. 432-438. København: Rosenkilde og Bagger. [2 $\left.2^{\text {nd }} \mathrm{ed.}\right]$

Tacitus, Publius Cornelius

1954 Germania. London: Harvard University Press(Loeb Classical Library). 


\section{Wikander, Stig}

1978 Araber, vikingar, väringar. Lund: Svenska Humanistiska Förbundet. (Svenska Humanistiska Förbundet, 90) 